\title{
Perilaku Bullying Mahasiswa Kesehatan
}

\section{Lingga Kusuma Wardani , Fajriansyah}

STIKes Surya Mitra Husada

linggakusumawardani@gmail.com

\begin{abstract}
ABSTRAK
Bullying behavior is an act of intimidation by a strong side against a weak side. Bullying behavior can be grouped into four categories: physical bullying, verbal bullying, social bullying and cyber bullying. Students are in the transition from adolescence to adult. The purpose of this study is to explore the behavior of bullying by healthstudents.The design of this research is qualitative with case study approach. Using the Snowball Sampling technique obtained samplemostly students of Nurse Education Program Studyof the number 4 informants. Data collection conductedindept interview, the result was analyzed using inductive thinking process.Data analyzedshowed four themes of knowledge deficits, bullying awareness, repetitive behavior, and self impact.The results showed that students know what is bullying behavior, but bullying University still done by intimidating verbally and with physical strength.
\end{abstract}

Keywords: Bullying Behavior, Student, Intimidation

How to Cite: Wardani, L.K \& Fajriansyah. (2017). Perilaku Bullying mahasiswa kesehatan. Journal Of Nursing Practice. 1(1). 17-23. 


\section{LATAR BELAKANG}

Pendidikan adalah salah satu lembaga formal yang ditempuh oleh sebagian besar individu untuk memperoleh dan mengembangkan pengetahuan, keterampilan dan moral. Lingkungan pendidikan seharusnya dapat menjadi sebuah wadah yang sehat, kondusif dan aman agar individu dapat bereksplorasi dan mengembangkan diri di dalamnya. Akan tetapi akhir-akhir ini kerap terjadi berbagai perilaku dan aksi kekerasan yang mengkhawatirkan di lingkungan pendidikan, baik yang dilakukan guru terhadap siswa antar siswa maupun antar mahasiswa. Salah satu fenomena yang banyak beredar di media adalah kasus kekerasan antar siswa atau mahasiswa yang terjadi di lingkungan sekolah atau kampus yang dikenal dengan istilah bullying.Banyaknya fenomena bullying yang terjadi dalam institusi pendidikan karena ada beberapa karakteristik siswa atau mahasiswa yang membuatnya rentan menjadi korban bullying.

Berdasarkan survei yang dilakukan oleh Latitude News di 40 negara. Salah satu faktanya yang ditemukan adalah pelaku bullying biasanya para siswa atau mahasiswa laki-laki. Sedangkan siswi atau mahasiswi lebih banyak menggosip ketimbang melakukan aksi kekerasan dengan fisik. Dari survei tersebut juga terdapat negara-negara dengan kasus bullying tertinggi di seluruh dunia. Lima negara dengan kasus bullying tertinggi, pada posisi pertama ditempati oleh Jepang, Indonesia, Kanada, Amerika Serikat, dan Finlandia (Uniquepost, 2014). Data Komisi Perlindungan Anak (KPAI) menyebutkan, sejak 2012 hingga 2015, sedikitnya dari 2 ribu anak di seluruh Indonesia, sebanyak 87 persennya mengalami kasus kekerasan yang di dalamnya termasuk bullying.Hasil Survei yang dilakukan oleh Yayasan Semai Jiwa Amini (SEJIWA, 2008) kekerasan bullying di tiga kota besar di Indonesia, yaitu Yogyakarta, Surabaya, dan Jakarta mencatat terjadinya tingkat kekerasan sebesar 67,9\% di tingkat Sekolah Menengah Atas (SMA) dan 66,1\% di tingkat Sekolah Menengah Pertama (SMP). Kekerasan yang dilakukan sesama siswa tercatat sebesar $41,2 \%$ untuk tingkat SMP dan 43,7\% untuk tingkat SMA dengan kategori tertinggi kekerasan psikologis berupa pengucilan. Peringkat kedua ditempati kekerasan verbal (mengejek) dan kekerasan fisik (memukul). Gambaran kekerasan di SMP di tiga kota besar yaitu Yogya: 77,5\% (mengakui ada kekerasan); Surabaya: 59,8\% (ada kekerasan); Jakarta : 61,1\% (ada kekerasan).

Beberapa faktor yangterlihat dalam perilaku bullying, yaitu faktorpribadi anak itu sendiri, faktor keluarga, lingkungan, maupun sekolah atau kampus. Fakor-faktortersebut baik yang bersifat individumaupun kolektif, memberi kontribusikepada seseorang anak sehingga akhirnya anak melakukan tindakanbullying.

Menurut Ken Rigby (2010) untuk mengatasi maraknya perilaku bullying dan dampaknya di dunia pendidikan dapat dilakukan dengan 6 cara berikut, yaitu : dukungan disiplin (traditional disciplinary approach), memberikan dukungan pada korban (strengthening the victim), mediasi antara korban dan pelaku (mediation), mengembalikan keharmonisan antara pelaku dan korban (Restorasi practice), metode dukungan kelompok (support group method), dan metode kelompok peduli (method of shared concern).Tujuan penelitian ini untuk mengeksplorasi perilaku bullyingmahasiswa kesehatan. 


\section{METODE PENELITIAN}

Desain penelitian ini adalah kualitatif dengan pendekatan studi kasus. Menggunakan teknik snowball sampling dengan sampel beberapa mahasiswa Prodi Ners STIKES Surya Mitra Husada Kediri yang berjumlah 4 informan. Pengumpulan data dilakukan dengan wawancara mendalam menggunakan wawancara semi-terstruktur, hasilnya dianalisis menggunakan proses berfikir induktif.

\section{HASIL PENELITIAN}

KARAKTERISTIK SUBYEK

Tabel 1. Karakteristik Informan dalam Penelitian Perilaku Bullying Mahasiswa Kesehatan

\begin{tabular}{lcc}
\hline Informan & $\begin{array}{c}\text { Usia } \\
\text { (th) }\end{array}$ & Semester \\
\hline Informan 1 & 21 & 6 \\
Informan 2 & 23 & 10 \\
Informan 3 & 22 & 8 \\
Informan 4 & 22 & 8 \\
\hline
\end{tabular}

Sumber: hasil analisa data, Tahun 2017

\section{PEMBAHASAN}

\section{Defisit Pengetahuan}

Tema defisit pengetahuan yang dilakukan oleh mahasiswa adalah perkelahian, balas dendam pada orang lain, membicarakan orang lain baik secara verbal maupun melalui sosial media, serta menjelek-jelekan orang lain di lingkungan kampus. Perkelahian yang dimaksudkan menggunakan kekuatan fisik pada orang lain dengan tujuan pribadi, membicarakan orang lain dilakukan pelaku berupa meyebarkan berita tidak benar (hoax) melalui kelompok diskusinya maupun melaui media sosial yang dimiliki. Semua hal yang dilakukan dengan maksud pribadi dari pelaku. Hal ini masih terjadi di lingkungan Kampus.

Hal ini diperkuat oleh teori Coloronso (2007) yang mengatakan Perilaku bullying adalah tindakan intimidasi yang dilakukan pihak yang kuat terhadap pihak yang lemah. Sedangkan menurut Flynt \& Morton (2006) bullying adalah suatu perilaku agresif yang diniatkan untuk menjahati atau membuat individu merasa kesusahan, terjadi berulang kali dari waktu ke waktu dan berlangsung dalam suatu hubungan yang tidak terdapat keseimbangan kekuasaan atau kekuatan di dalamnya. Bullying dapat terjadi di berbagai tempat, kapanpun, dan pada siapa saja. Penelitian sebelumnya menunjukkan bahwa bullying dapat terjadi di rumah tangga, sekolah dan lingkungan kampus (Syakrani \& Mafriana, 2005).

Dari hal diatas dapat disimpulkan bahwa perilaku bullying bukan merupakan hal asing bagi mahasiswa, namun masih marak terjadi di semua lini dunia pendidikan, baik itu tingkat dasar sampai tingkat perguruan tinggi. Hal ini 
dikarenakan mahasiswa masih termasuk dalam periode tengah kehidupan, yang mana mahasiswa masih mencari jati diri dan cenderung untuk mencoba hal-hal baru, baik itu yang positif maupun yang negatif.

\section{Kesadaran Tentang Bullying}

Tema kesadaran tentang bullying yang dilakukan oleh mahasiswa meliputi perilaku bullying yang disadari dan tidak. Beberapa pelaku menyatakan bahwa mereka sadar melakukan perilaku bullying bahkan mengatakan hal itu sudah menjadi sebuah hal yang biasa untuk dilakukan. Sedangkan ada pula pelaku yang menyatakan bahwa tidak pernah melakukan bullying walaupun tindakannya termasuk perilaku bullying. Hal ini disebabkan bullying sudah dianggap menjadi hal yang biasa di lingkungan pelaku maupun pelaku itu sendiri.

Hal ini sesuai dengan pendapat Ken Rigby (dalam Astuti, 2008) yang menyatakan Bullying adalah aktifitas yang sadar, disengaja yang dimaksudkan untuk melukai, menanamkan ketakutan melalui ancaman agresi lebih lanjut serta dapat menjadi sebuah kebiasaan berulang-ulang.

Perilaku buruk yang dilakukan secara sadar dari waktu ke waktu apabila dibiarkan terus akan menjadi sebuah kebiasaan. Sama seperti bullying, jika selalu dilakukan maka perilaku ini akan menjadi sebuah kebiasaan dan dianggap lumrah terjadi. Padahal pada hakikatnya perilaku tersebut merupakan perilaku yang salah. Apabila terus dibiarkan maka akan terlahir generasi yang membenarkan semua kesalahan yang dilakukan

\section{Perilaku Berulang}

Tema perilaku berulang yang dilakukan oleh mahasiswa meliputi realisasi bentuk seperti mengejek, membicarakan orang lain, berkelahi, serta mengancam dengan frekuensi yang tidak kurang dari 2 kali, timer perilaku dilakukan di dalam maupun di luar kampus, dan akar masalah dari perilaku yang dilakukan adalah eksistensi dari pelaku. Pelaku ingin menunjukan eksistensinya pada korban.

Hal ini diperkuat dengan teori Priyatna (2010) yang menyatakan bentuk bullying yang secara umum dapat dikelompokkan ke dalam empat kategori: bullying fisik, bullying verbal, bullying sosial dan Cyberbullying. Teori Bandura mengatakan bahwa perilaku manusia sebagian besar merupakan perilaku yang dipelajari. Demikian halnya dengan perilaku kekerasan termasuk di dalamnya bullying. Teori belajar sosial yang dipelopori oleh Bandura menyatakan bahwa perilaku merupakan pengalaman yang dipelajari dari masa lalu, apakah melalui pengamatan langsung (imitasi), pengukuh positif, dan karena stimulus diskriminatif. Pengamatan pada orang disekelilingnya yang berperilaku kekerasan atau mungkin mengontrol perilaku kekerasan dan kemudian menirukannya sertaa mengulangi hal tersebut di masa yang akan datang. (Rigby \& Slee dalam Boeree, 2006). Simbolon (2012) mengatakan bullying dapat terjadi bukan hanya di asrama tetapi juga di lingkungan kampus terutama di tempat-tempat yang bebas dari pengawasan dosen. Pelaku bullying bebas melakukan tindakannya ketika orang-orang yang dianggap memiliki kewenangan di kampus sedang tidak mengawasi mereka. Tempat-tempat yang paling dianggap kondusif untuk melakukan bullying adalah kamar mandi, kamar kosong, bahkan kamar hunian korban ketika penghuni lainnya tidak ada di tempat. Ia juga mengatakan beberapa 
faktor penyebab terjadinya bullying berupa faktor internal dan eksternal. Faktor internal adalah karakteristik kepribadian, kekerasan yang dialami sebagai pengalaman masa lalu, sikap keluarga yang memanjakan anak sehingga tidak membentuk kepribadian yang matang. Faktor eksternal yang menyebabkan kekerasan adalah lingkungan, dan budaya.

Pada mahasiswa Pria lebih menekankan keuatan fisik, sedangkan wanita lebih bermain dengan kata-kata atau dengan cyber bullying (melalui media social ). Tidak menutup kemungkinan mahasiswa wanita bisa melakukan bullying fisik pada orang lain maupun sebaliknya mahasiswa pria menjadi tukang gosip dan tukang penyebar berita hoax. Ada pengaruh tempat dimana pelaku melakukan bullying kepada korbannya. Tempat sepi bisa menjadi pilihan utama. Pelaku lebih memilih tempat yang tidak terlihat orang banyak. Tapi berbeda konteksnya jika pelaku sudah merasa nyaman melakukan bullying. Ruangan sepi atau tempat yang jarang terlihat sudah bukan menjadi persoalan. Hal ini dapat terjadi pada social bullying, contohnya membicarakan gosip atau berita hoax. Hal ini tidak memandang tempat sepi atau ruangan kosong, yang menjadi fokus pelaku adalah teman, karena pelaku butuh objek lain (teman) sebagai penyalur gosip atau berita hoax. Latar belakang setiap orang tidaklah sama dalam melakukan sesuatu. Perilaku bullying yang dilakukan oleh mahasiswa umumnya akan lebih cenderung mengarah pada balas dendam, ketakutan ataupun ingin menunjukan eksistensi pribadi pada orang lain. Perilaku ini tidak dibenarkan karena berdampak negatif pada korban. Pelaku bullying mendapatkan kepuasan tapi tidak halnya dengan korban bullying itu sendiri. Korban akan merasa tertekan dan hal yang paling dikhawtirkan korban akan meniru perlakuan yang ia terima kepada orang. Apabila hal tersebut terjadi, maka kasus ini akan menjadi rantai yang terus bersambung.

\section{Self Impact}

Tema self impact yang dilakukan oleh mahasiswa meliputi hal positif dan negatif yang dirasakan oleh pelaku. Hal positif yang diperoleh Pelaku bullying adalah apa yang mereka inginkan terwujud, dalam hal ini adalah latar belakang pelaku melakukan bullying. Sedangkan dampak negatif yang diperoleh oleh pelaku adalah pelaku kehilangan orang-orang terdekat, stigma sosial menjadi jelek dan harus berurusan di kantor Polisi untuk mempertanggung jawabkan perbuatannya.

Hal ini diperkuat dengan pendapat Andrew Mellor (2000) yang mengatakan dampak bullyingbagi korban diantara adalah depresi, gelisah, rasa tidak aman saat berada di lingkungan sekolah, penurunan semangat belajar dan prestasi akademis, dalam kasus yang cukup langka anak-anak korban bullyingmungkin akan menunjukkan sifat kekerasan.Tak hanya korban bullying, mereka yang melakukan bullying juga terkena dampaknya. Orang-orang yang melakukan bullyingcenderung untuk berperilaku kasar/abusif, melakukan kriminalitas, tawuran, terlibat dalam vandalisme, penyalahgunakan obat-obatan dan alkohol, terlibat dalam pergaulan bebas. Menurut Simbolon (2012) bullyingmengakibatkan korbannya menjadi putusasa, menyendiri, tidak mau bergaul, tidakbersemangat, bahkan berhalusinasi. Berbeda halnya dengan pelaku, mereka merasasemakin memiliki wibawa. Pelaku jugamendapatkan kepuasan 
setelah melakukan tindakan tersebut. Tapi pada beberapa kasus pelaku mengaku ada akibatlain yang dirasakan setelah melakukanperbuatannya yaitu rasa malu dan minder.Ungkapan ini menunjukkan bahwa lingkungan sosial menjadikan pelaku merasaterhukum atas perbuatannya.

Perilaku bullying memberikan dampak positif berupa wibawa yang meningkat, eksistensi yang muncul, dan dihormati orang lain. Namun banyak hal negatif lain yang juga muncul dari hal tersebut, diantaranya pelaku akan mengalami Over confidence (percaya diri berlebihan), memiliki harga diri yang tinggi dan terkesan sombong. Pelaku juga seakan akan mengalami adiksi terhadap bullying, yaitu merasa kehilangan wibawa dan harga diri apabila tidak melakukan bullying. Akibatnya, perilaku bullying akan selalu diulangi oleh pelaku untuk mempertahankan apa yang ia miliki. Hal kedua yang akan di peroleh oleh pelaku adalah tercorengnya stigma sosial pelaku, dikarenakan dampak sosial yang menyebabkan pelaku dipandang buruk di mata masyarakat umum atas perbuatan yang ia lakukan. Selain itu, pelaku juga akan dijauhi orang-orang sekitar karena merasa jenuh dengan sikap pelaku.

\section{KESIMPULAN DAN SARAN}

\section{Kesimpulan}

1. Penelitian ini menghasilkan empat tema yaitu defisit pengetahuan, kesadaran tentang Bullying, perilaku berulang, dan Self Impact.

2. Tema defisit pengetahuan yang dilakukan oleh mahasiswa adalah perkelahian, balas dendam pada orang lain, membicarakan orang lain baik secara verbal maupun melalui sosial media, serta menjelek-jelekan orang lain di lingkungan kampus. Perkelahian yang dimaksudkan menggunakan kekuatan fisik pada orang lain dengan tujuan pribadi, membicarakan orang lain dilakukan pelaku berupa meyebarkan berita tidak benar (hoax) melalui kelompok diskusinya maupun melaui media sosial yang dimiliki. Semua hal yang dilakukan dengan maksud pribadi dari pelaku. Hal ini masih terjadi di lingkungan Kampus.

3. Tema kesadaran tentang bullying yang dilakukan oleh mahasiswa meliputi perilaku bullying yang disadari dan tidak. Beberapa pelaku menyatakan bahwa mereka sadar melakukan perilaku bullying bahkan mengatakan hal itu sudah menjadi sebuah hal yang biasa untuk dilakukan. Sedangkan ada pula pelaku yang menyatakan bahwa tidak pernah melakukan bullying walaupun tindakannya termasuk perilaku bullying. Hal ini disebabkan bullying sudah dianggap menjadi hal yang biasa di lingkungan pelaku maupun pelaku itu sendiri.

4. Tema perilaku berulang yang dilakukan oleh mahasiswa meliputi realisasi bentuk seperti mengejek, membicarakan orang lain, berkelahi, serta mengancam dengan frekuensi yang tidak kurang dari 2 kali, timer perilaku dilakukan di dalam maupun di luar kampus, dan akar masalah dari perilaku yang dilakukan adalah eksistensi dari pelaku. Pelaku ingin menunjukan eksistensinya pada korban.

Tema self impact yang dilakukan oleh mahasiswa meliputi hal positif dan negatif yang dirasakan oleh pelaku. Hal positif yang diperoleh Pelaku 
bullying adalah apa yang mereka inginkan terwujud, dalam hal ini adalah latar belakang pelaku melakukan bullying. Sedangkan dampak negatif yang diperoleh oleh pelaku adalah pelaku kehilangan orang-orang terdekat, stigma sosial menjadi jelek dan harus berurusan di kantor Polisi untuk mempertanggung jawabkan perbuatannya.

\section{DAFTAR PUSTAKA}

Allen K, 2006. Bullying and Self-Esteem: Is There A Connection?. Impact Training, Inc.

Fitri, H. 2013. Hubungan antara Harga Diri dan Disiplin Sekolah dengan PerilakuBullying pada Remaja. Jurnal Penelitian Humaniora, Vol.14 No.1 Hal 9-16.

Liow, C. J., \& Andriani, I. (2009). Hubungan Tindakan Bullying di Sekolah Dengan Self Esteem, 3, 3-7.

Rigby, K. 2008. New Perspectives on Bullying. London : Jessica Kingsley

Saifullah, 2016. Hubungan Konsep Diri dengan Bullying pada Siswa-Siswi SMP di SMP 16 Samarinda. Jurnal Psikologi Unmul,Vol. 4 No.2 hal 3-12

Setiawati, R. O. 2010. Waspadalah Harga Diri Anak Rendah Karena Bullying. Psikologi Plus. Vol. IV No. 7 hal 12-16 Januari 2012

Spade JA, 2007. The Relationship Between Student Bullying Behaviors and Self Esteem. A Dissertation. College of Bowling Green State University

Yolan, 2012. Negara-negara dengan Kasus Bullying Tertinggi, Indonesia diUrutan Ke-2. http://uniqpost.com. Diakses 12 November 2016

Yusuf, S. 2012. Psikologi Perkembangan Anak dan Remaja. Bandung : PT.Remaja Rosdakarya 